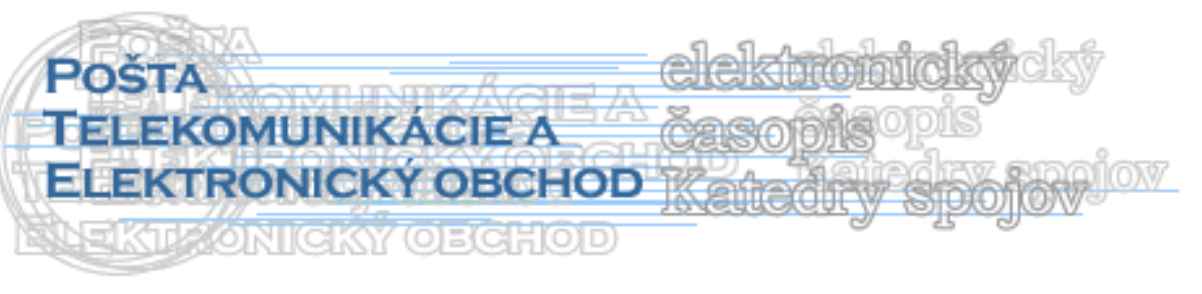

\title{
DATABANKING - TRETIA GENERÁCIA ELEKTRONICKÉHO BANKOVNÍCTVA
}

\author{
Juraj Vaculík ${ }^{1}$, Peter Benech ${ }^{2}$
}

\begin{abstract}
Anotácia : V príspevku je predstavená technológia Databankingu ako tretej generácie elektronického bankovníctva a popis jej rozhrania, spolu s príkladmi zdrojových kódov. Technológia Databankingu je implementovaná ako XML Web služba.

The Databanking technology is here introduced as the third generation of electronic banking including its description of interface and source code examples too. The Databanking technology is implemented as as an XML Web Service.
\end{abstract}

\section{Čo je Databanking}

V roku 2004 spustila Slovenská sporitel'ňa úplne novú službu elektronického bankovníctva - Databanking ako jeho tretiu generáciu (prvá - Homebanking, druhá Internet Banking). Je to dátové komunikačné rozhranie umožňujúce formou Web služby, čiže formou komunikácie cez internetový protokol HTTP a XML dokument kompletnú správu klientových účtov. Pointou bolo oddelit' údaje od dizajnu užívatel'ského prostredia a umožnit' tak klientovi alebo tretej strane (vývojárom) integrovat' funkcie pre správu účtov Slovenskej Sporitel'ne do vlastných aplikácií. Databanking je unikátne inovatívne rozhranie, ktoré sa nevyskytuje $\mathrm{v}$ iných bankách a údajne dokonca ani $\mathrm{v}$ žiadnej banke $\mathrm{v}$ rámci Európy, ide tak o prototyp.

Rozhranie Databankingu je stále v procese evolučného vývoja a Slovenská Sporitel'ňa plánuje v budúcnosti (v priebehu pol roka až rok) ju implementovat' ako štandardnú SOAP Web službu.

\subsubsection{Charakteristika produktu}

Služba Databanking je jednoduchou, bezpečnou a vel'mi efektívnou cestou ako integrovat' elektronické bankovníctvo Slovenskej sporitel'ne priamo do vášho účtovného alebo ekonomického systému. Databanking funguje prostredníctvom štandardizovaného rozhrania, ktoré umožňuje bezpečnú automatizovanú výmenu dát medzi klientom a bankou. Službou Databanking si možno prispôsobit' elektronické bankovníctvo individuálnym užívatel'ským potrebám. Súčasne sa minimalizujú riziká vzniku chýb spojené s manuálnymi exportnými a

\footnotetext{
${ }^{11}$ Doc. Ing. Juraj Vaculík, PhD., Žilinská univerzita, fakulta PEDaS, katedra spojov, vedúci oddelenia EKaS mail : juvac@pedas.utc.sk,

${ }^{22}$ Ing. Peter Benech, Žilinská univerzita, fakulta PEDaS, katedra spojov, mail: benech@inmail.sk
} 
importnými operáciami, ktoré sú nutné pri využívaní iných služieb (Homebanking, Internet Banking).

\subsubsection{Komu je Databanking určený}

Databanking je určený najmä pre malé a stredné spoločnosti, ktoré potrebujú:

- denne spracovávat' väčší počet transakcií,

- prispôsobit' funkcie elektronického bankovníctva svojim individuálnym potrebám,

- integrovat' elektronické bankovníctvo do podnikových procesov (workflow),

- automatizovat' bankové operácie,

- znížit’ riziko vzniku chýb. klientov.

Databanking možno taktiež využit' $\mathrm{k}$ vývoji užitočných aplikácií pre retailových

Cena a poplatky - využívanie služby Databanking je bezplatné.

Podmienkou aktivácie služby Databanking je:

- otvorený bežný účet - SPORObusiness-konto,

- aktivácia služieb elektronického bankovníctva - SPORO24.

Po splnení týchto podmienok môže klient automaticky používat' službu Databanking, ak jeho softvér túto službu podporuje.

\subsubsection{Výhody Databankingu oproti Homebankingu a Internet Bankingu:}

- automatizácia výmeny dát medzi bankou a systémom klienta,

- možnost' zníženia prevádzkových nákladov súvisiacich so správou služby Homebanking,

- redukcia rizika vzniku chýb vd’aka automatizácii,

- možnost' súčasne využívat' a kombinovat' rôzne kanály na prístup $\mathrm{k}$ tomu istému bankovému účtu (príkaz na úhradu faktúry, ktorý bol zadaný cez Databanking môže byt' podpísaný dodatočne napr. cez Internet Banking),

- prepojitel'nost' elektronického bankovníctva aj na iné systémy (možnost' systémovej integrácie): užívatel'ské rozhranie (databankingový modul) môže byt' prispôsobený podla individuálnych požiadaviek klienta a možností dodávatel'a ekonomického systému,

- klient sa môže sám rozhodnút', ktoré funkcie elektronického bankovníctva a akým spôsobom integrovat' do svojich podnikových procesov (workflow). 


\section{Princíp fungovania Databankingu}

Obr. 1 Schéma fungovania služby Databanking

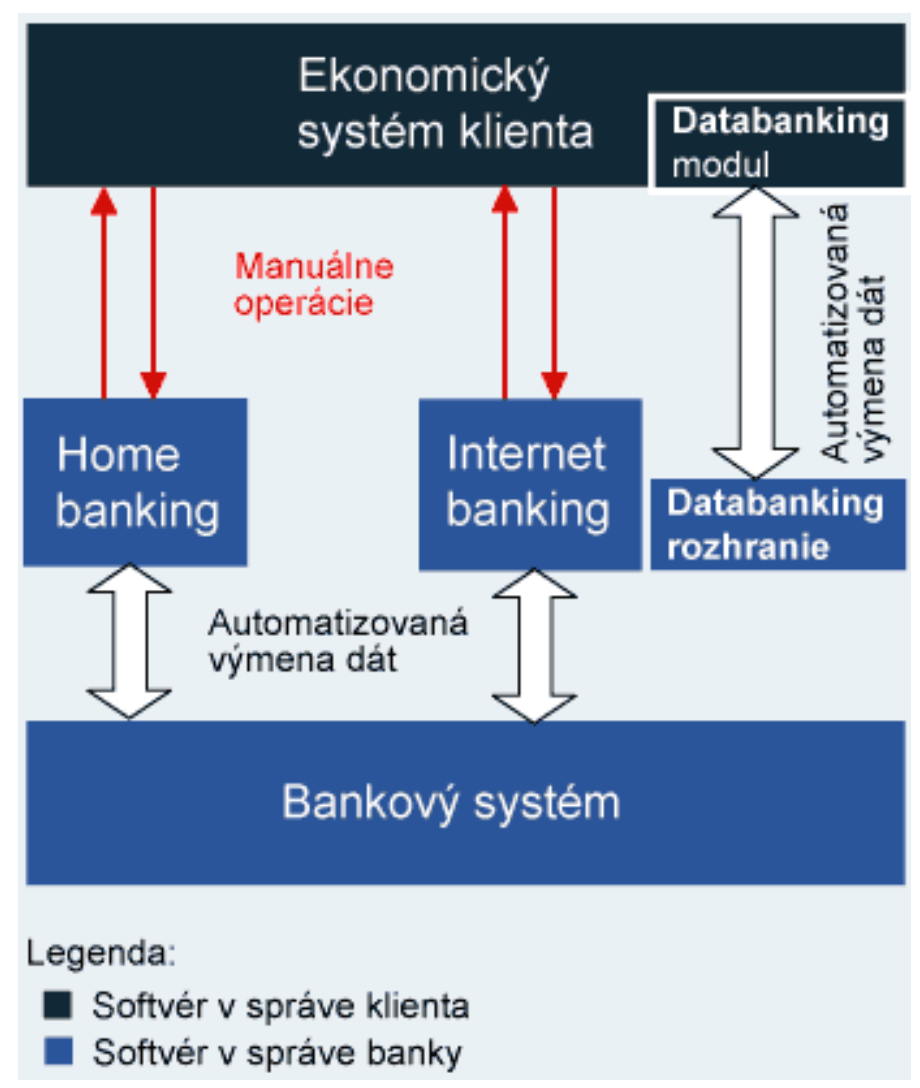

Databanking je v súčasnosti implementovaný v nasledujúcich softvéroch:

- $\quad$ FINUS - ANASoft APR, s.r.o.

- DOMUS - ANASoft APR, s.r.o.

- Money S3 10.010 - CÍGLER SOFTWARE, a. s.

- DATALOCK W - DATALOCK, s.r.o.

- $\quad$ ELALL 3.7 - ELALL spol. s r.o.

- $\quad$ SRS 2000 - EMEL BRATISLAVA, s.r.o.

- HUMAN, HUMANET - HOUR, spol. s r. o.

- EKO - IFOsoft v.o.s.

- OCU - IFOsoft v.o.s.

- $\quad$ BD - IFOsoft v.o.s.

- OMEGA - KROS, s.r.o.

- $\quad$ SVB Správca V 1.8 - Ing. Michal Mikuláš - mMSoft

- $\quad$ MRP - MRP-Company, s.r.o.

- Millenium - TELEGRAFIA, s.r.o.

- $\quad$ Microsoft Business Solutions - Navision - TELEGRAFIA, s.r.o.

\subsubsection{Funkcionalita Databankingu}

Aplikácia Internetbanking XML slúži na automatizované prepojenia aplikácie klienta (napríklad účtovníctvo alebo iný ekonomický systém) so službou Internetbanking prostredníctvom https žiadostí a xml odpovedí. K dispozícii sú tieto funkcie:

- prihlásenie,

- odhlásenie, 
- prehl'ad účtov,

- zadanie príkazu na úhradu (jednoduchý príkaz),

- podpísanie jednoduchého príkazu na úhradu,

- zadanie príkazu na úhradu do zoznamu (hromadný príkaz),

- zoznam príkazov v hromadnom príkaze na úhradu,

- podpísanie hromadného príkazu na úhradu,

- prehl'ad obratov podl'a podmienok filtrovania,

- prehl'ad obratov podl'a podmienok filtrovania.

Práca so systémom je obmedzená na autorizačný predmet Heslo a elektronický osobný kl'úč (EOK) a certifikačný predmet EOK. Použitie GRID karty na certifikáciu platieb nie je možné, čo je zatial' istou evolučnou a komparatívnou nevýhodou, ked'že bezpečnost' rozhrania Databankingu je rovnaká ako bezpečnost' rozhrania Internet Bankingu.

\subsubsection{Technický popis komunikácie}

Aplikácia klienta komunikuje so systémom Internetbanking XML prostredníctvom HTTPS požiadaviek na adrese https://ib.slsp.sk/ebanking/* so špecifikovanými parametrami odovzdanými GET alebo POST metódou. Komunikácia klienta s bankou je šifrovaná protokolom SSL. Aplikácia klienta musí podporovat' prácu s cookies. Odpoved’ou servera na požiadavku je xml súbor vyhovujúci DTD (Document Type Definition) ibxml.dtd. DTD xml dokumentu je navrhnuté tak, že vo výstupnom súbore sa vždy nachádza práve jedna "vetva" xml stromu. Ide o chybovú vetvu (<error/>), alebo vetvu s požadovaným výstupom $(<$ result/>). Jazyková mutácia textových položiek vo výstupe závisí od zvoleného jazyka klienta. Všetky texty sú prekladané $\mathrm{v}$ rovnakom rozsahu ako $\mathrm{v}$ prípade HTML verzie aplikácie.

HTTPS požiadavka musí obsahovat' všetky uvedené parametre; v prípade, že nejaký parameter nie je využitý, musí sa poslat' bez hodnoty.

Root (koreňový) element výstupu je vždy $<\mathrm{ibxml} />$. Tento element obsahuje $\mathrm{v}$ prípade chyby práve jeden element $\mathrm{s}$ názvom <error/ $>\mathrm{a} v$ prípade úspešného spracovania požiadavky obsahuje práve jeden element $\mathrm{s}$ názvom $<$ result/>, ktorý obsahuje odpoved' na požiadavku klienta.

Chyby sa delia na dva druhy. V prípade zadania neprípustnej hodnoty niektorého parametra sa vracia <checker/> error (formálna kontrola údajov pred spracovaním). Checker error $\mathrm{v}$ sebe obsahuje zoznam nesprávne zadaných údajov. V prípade inej chyby spracovania $<$ process/> error. Process error v sebe obsahuje identifikáciu chyby, ktorá sa vyskytla.

\subsubsection{Záver}

Budúcnost' vývoja služieb tohto typu je v širšom kontexte aj vecou povedomia bánk, eobchodníkov a štátu o potenciáli technologického rozvoja formou (XML) Web služieb, ktoré umožňujú efektívnu výmenu informácií medzi rôznymi systémami, distribúciu a decentralizáciu obchodných procesov. Web služby sa totiž dajú rôzne naväzovat' a komponovat', jediným obmedzením je latencia fyzického prenosu údajov. Povedomie o XML a jeho možných využitiach $\mathrm{k}$ nám preniká dost' pozvol'na.

Firmy pre zákazníkov i partnerov vytvárajú vizuálne atraktívne webové prezentácie spolu s informáciami, ktoré poskytujú. Je nelogické, aby firmy samé od seba začali poskytovat' aj iné cesty poskytovania obsahu informácií o sebe než formou webu, pretože pre vyvíjanie formy čistých údajov, zbavených akéhokol'vek atraktívneho a marketingovo 
kontrolovatel'ného dizajnu nie je záujem. Existuje totiž nedostatok vedomostí o potenciáli zefektívnenia obchodnej komunikácie a zlepšenia produktivity. Preto zavádzanie Web služieb slávi najväčší úspech pri kolektívnom záujme príslušného ekonomického odvetvia, ktorý volá po zefektívnení komunikácie medzi sebou, vyššej interoperabilite a interkonektivite. XML má tú výhodu, že aj ked' si rôzne, maličké skupinky firiem, neschopné spoločnej dohody zavedú rôzne komunikačné štandardy, existujú nástroje pre l'ahkú transformáciu údajov medzi rôznymi schémami internetovej komunikácie.

\section{Literatúra}

[1.] Databanking. [online]. Slovenská sporitel’ňa. Dostupné na: http://www.databanking.sk

[2.] BENECH P. Aplikácia internetových technológií velektronickom bankovníctve, diplomová práca, , Žilinská univerzita, katedra spojov, 2005/2006,

[3.] MADLEŇÁK R., Elektronický obchod, skriptá, EDIS Žilinská univerzita 2004, ISBN 808070-192-X,

[4.] MiČEKOVÁ A KOL. : Bankovníctvo - čast' elektronické bankovníctvo, skriptá, EDIS Žilinská univerzita 2006, ISBN 